\title{
Place branding gathering momentum
}

\author{
Mihalis Kavaratzis $^{1} \cdot$ Charles Dennis $^{2}$
}

Published online: 28 March 2018

(C) Macmillan Publishers Ltd., part of Springer Nature 2018

\section{Introduction}

The articles included in this Special Issue were presented at the Inaugural Conference of the International Place Branding Association, which was hosted by Middlesex University in London in December 2016. The conference gathered a great number of scholars, researchers, practitioners and $\mathrm{PhD}$ students all working on place branding and related issues. During the three days of the PhD Colloquim and the main conference, the delegates' interest in several aspects of place and destination branding encouraged intense discussions ranging from light-hearted but creative conversations to serious but inspiring disagreements. The programme included three relevant and effective keynote speeches: an 'academic' one by P.O. Berg (from Stockholm Business School), a 'consultancy' one by Bill Baker and a 'practitioner' one by Marit Høvik Hartmann (from the city of Oslo). A series of topics, ideas, methods and examples from all over the world were examined at the conference's five strands of presentations. As the inaugural conference of the IPBA, the conference provided the perfect opportunity to address several pressing questions around place branding.

Mihalis Kavaratzis

mk302@leicester.ac.uk

Charles Dennis

C.Dennis@mdx.ac.uk

1 University of Leicester School of Business, Ken Edwards Building, University Road, Leicester LE1 7RH, UK

2 Business School, Middlesex University, Hendon Campus, The Burroughs, London NW4 4BT, UK

\section{The pressing issues}

An evident effort of the place branding scholarly community, as demonstrated by the presentations as well as informal discussions during the conference, is to develop a set of clear and widely accepted theoretical foundations. This is particularly useful for the future of place branding as an academic field and, perhaps more importantly, as an applied practice. Certain emphases seem to complement older and more traditional inquiries. One of them is the stronger focus on stakeholders, their significance, their role and their further engagement in place branding. Another one is the exploration of approaches alternative to a purely managerial focus, with extensions into the critical concerns raised by human geographers, sociologists and media scholars. Issues of identity then come onto the surface and were strongly present at the conference. Of course, place brands are now more and more examined as cultural phenomena carrying and re-producing cultural meanings and values. Generally, the presentations at the conference, as well as the articles included in this Special Issue showed that we are readier than ever to deal with the challenges of place branding. These include the complexity of places as branded entities, the multiplicity of stakeholder groups and their conflicting interests. They also evidently include the proposition and refinement of suitable tools to guide practical application as well as to measure the effectiveness of place branding activities. Explorations of the tensions around branding a single place as a place of residence, a place to visit and a place to invest are also apparently more common than in the past. All these and many more provided the topics of many creative debates. Each article in this Special Issue separately provides an 'entrance point' to the wider issues that continue to puzzle commentators and practitioners. The authors of the contributions included 
here collectively assess the current state and provide a valuable overview of the significant issues that will affect the future of place branding and will determine its further development and effectiveness.

\section{The articles of the special issue}

The first article, 'Patterns of Place Promotion, Place Marketing and/or Place Branding in Dutch Municipalities' by Martin Boisen, Peter Groote, Kees Terlouw and Oscar Cowenberg provides a very useful critical assessment of the popularity of place branding as a practice. The authors were able to determine the extent to which Dutch Municipalities implement place promotion, place marketing and place branding by analysing four different elements. First, whether place promotion, marketing and branding are included as municipal policies. Second, whether there exists an identifiable organisation with the mandate to devise relevant strategies and implement relevant projects. Third, whether such organisations are internal or external to the municipality and finally, fourth, whether such organisations are responsible for part or all of the place marketing effort (i.e. if place marketing is understood in an integrated manner or there are sperate organisations for the attraction of investment, residents, tourism, etc.). An important feature of the authors' study is that they have included all municipalities of the country, thus going beyond the usual limit of investigations to a single municipality or to big cities and popular tourism destinations. The study confirms that the Netherlands as a country where place marketing is a well-established practice. In the vast majority of Dutch municipalities, place marketing is within the policies, with one-third of them having a separate place marketing organisation. Larger cities tend to have this externally organised while smaller cities internally. The size of the city seems to influence the degree of integration of target audiences as well. Such a clearer view of implementation and institutionalisation of place marketing and place branding is very useful for the discipline and we full-heartedly agree with the authors' encouragement of comparative studies across more countries.

In the second article, 'Citizen Involvement, Place Branding and Mega Events-Insights from Expo Host Cities', Marta Herezniak and Magdalena Florek deal with the important topic of citizen involvement in place branding. The article starts with a detailed theoretical examination of stakeholder engagement within place branding. The authors provide a useful conceptualisation of the notion of citizen involvement using the existing place branding literature and supplementing it with ideas and frameworks stemming from public management as well as corporate marketing. Then, the authors undertake an empirical study focusing on mega events as they examine five host and candidate cities of the Expo. The article assesses the importance attributed to citizen engagement activities before, during and after the event. Amongst its many interesting findings, the study found out that while the perception of a need to engage with all stakeholders is high at the planning stage and during the event itself, after the event the momentum for engagement and participation seems to get lost. In their suggestions for further research, the authors include an investigation of the role of Social Media in mobilising local residents, something that, in our view, demonstrates significant potential for a better understanding and implementation of citizen participation in place branding strategies and activities.

In his article, 'City District Divergence Grid: A MultiLevel City Brand Positioning Tool', Virya Taecharungroj develops the very interesting practical tool 'City Divergence Grid' that assists cities in managing their positioning efforts and aligning their various sub-brands. The author undertakes a carefully selective literature review to identify and combine brand architecture strategies, suggestions around important city attributes and ideas around city/ brand personality to provide a matrix that aims at identifying and 'manipulating' the distinct brand elements of various city districts. The article includes a study of ten districts of Bangkok both to exemplify the potential use of the tool for cities and to illustrate its practical usefulness in developing branding and positioning strategies. Perhaps the most interesting, at least theoretically, aspect of the tool that is developed in the article is the fact that the City Divergence Grid might prove valuable in dealing with the issue of place scale; an issue that is arguably not dealt with satisfactorily thus far. If the tool can be helpful for districts within big cities (or what the author calls the multi-level nature of cities), it might also be used for neighbourhoods within a district or town, for towns within a region or perhaps even for cities within a country.

The article 'Place Branding Strategies in the Context of Smart Cities: The Songdo and Masdar City Cases', by Olga Kolotouchkina and Gildo Seisdedos examines place branding in relation to the fascinating context of digitally led urban innovations. In this, the article is as innovative in its exploration as its focus. Investigating place branding in the conditions of artificially built rather than organically developed places is both interesting and exciting. Branding a place that has no past but only a future is intriguing. The two case studies of the article Songdo City in South Korea and Masdar City in Abu Dhabi are places with no heritage, without locally embedded traditions and artefacts and without street-lie as found in most places. What is the role of branding in this peculiar context? Can we discuss and use the same branding principles, or do we need to change and adapt them? And what are the lessons to be learned for 
all places, especially considering that the future is guaranteed to hold more than a few digitally led developments for the most traditional of places? The authors assess that while these places have clearly-and perhaps inevitablystarted life as completely automated and centrally orchestrated place making (and management) endeavours, the tendency is to bring a lot more of the human element in all processes as the specific places turn into more 'real' cities.

The last article, 'Chinese and American "First Lady Diplomacy" and National Branding' is by Ning Wang and undertakes a detailed analysis of the role and activities of two 'first ladies', the American Michele Obama and the Chinese Peng Liyuan. In their triple position of direct influence, 'pillow' influence and public-figure influence both these ladies-along with a great number of other first ladies, including the iconic Jackie Kennedy-have done much to reinforce their husband's power as well as their own and, in this process, they have helped in subtle ways to brand their nation. The author demonstrates how this sort of soft power that is fundamental for public diplomacy, is strongly and quite effectively linked to the wider nation branding exercise. At the same time, the article is also an interesting exploration of the interdependency between the media and public diplomacy. It uses the idea of 'media framing' to discuss how global media report on the activities of the two first ladies and the examination concludes that they gave quite a favourable effect on the image of their countries. Their activities, their behaviour and, arguably, their sense of style, allow the two first ladies to play their role, especially in representing national culture and demonstrating good citizenship.

\section{Towards the future}

As described above, this Special Issue deals in different ways with assessments of the popularity of place branding practice, citizen involvement within wider place branding efforts, better positioning tools and issues of place scale, the future of place branding within digitally led innovation and the soft tools of public diplomacy. These demonstrate the diversity of themes, topics, approaches and priorities that characterise the field and that were evident at the inaugural conference of the International Place Branding Association. One of the main contributions of the newly established IPBA is to bring these approaches together not to assimilate them and find homogeneity but to allow them to interact, learn from each other and celebrate the divergence that makes place branding the fascinating field it is. Another main aim of the IPBA is to provide a sense of continuity for the field. There is already evidence of achieving this aim, not only in this Special Issue but also in the success of the Second Annual IPBA conference that took place in Swansea, Wales in December 2017. This Special Issue closes with a conference report on that second conference by Jasmin Sera.

The establishment of the International Place Branding Association is a significant development (perhaps second only to the establishment of this journal) that might help consolidate a lot of the accumulated knowledge and experience and make place branding academia work towards new beginnings for the field. It is clearly within the responsibilities of the IPBA - and, we know for a fact, also in its plans-to operate as a vehicle for further debates, collaborations and new initiatives. The remarkable success of the first two IPBA conferences (and, hopefully, the future success of the third that will take place in Macau in December 2018) signifies the momentum that is gathering for the advancement of the discipline. We believe that the articles of this Special Issue show the potential for further theoretical clarity and for the necessary practical relevance. We hope you will enjoy reading them and will find them inspiring enough to join the debate.

Mihalis Kavaratzis is Associate Professor of Marketing at the University of Leicester School of Business. His research focuses on place branding and tourism destination marketing. Mihalis is Founding Board Member of the International Place Branding Association and a Senior Fellow of the Institute of Place Management. He has published extensively in various academic journals and he is co-editor of Inclusive Place Branding (with M. Giovanardi and M. Lichrou, 2017), Rethinking Place Branding (with G. Warnaby and G.J. Ashworth, 2015) and Towards Effective Place Brand Management (with G.J. Ashworth, 2010).

Prof. Charles Dennis is Professor of Consumer Behaviour at The Business School, Middlesex University (UK); and Associate Editor in the Marketing section of Journal of Business Research. Charles has published in journals such as Journal of Business Research; Computers in Human Behavior; Psychology \& Marketing; Information Technology \& People; International Journal of Electronic Commerce; European Journal of Marketing; and Place Branding and Public Diplomacy. Books include Marketing the e-Business; Internet Retailing and Future Perspectives; and Objects of Desire: Consumer Behaviour in Shopping Centre Choice. 